\title{
PENGARUH VARIABEL FUNDAMENTAL TERHADAP HARGA SAHAM PERUSAHAAN GO PUBLIC DI BURSA EFEK INDONESIA (Studi pada Perusahaan Sub Sektor Batu Bara Pertambangan yang Terdaftar di Bursa Efek Indonesia Periode 2013-2016)
}

\author{
Anisa \\ Nisa44914@gmail.com \\ Universitas Ahmad Dahlan \\ Salamatun Asakdiyah \\ Salamatun_2009@yahoo.com \\ Universitas Ahmad Dahlan
}

\begin{abstract}
ABSTRAK
This study aims to determine the effect of liquidity (Current Ratio), leverage (Debt to Equity Ratio), profitability (Return on Equity) to the price of shares of mining coal companies listed on the Indonesia Stock Exchange in the period 2013-2016. The dependent variable used is the stock price, while the independent variable is liquidity (Current Ratio), leverage (Debt to Equity Ratio), and profitability (Return on Equity). The population in this study is a coal mining company listed on the Indonesia Stock Exchange as many as 22 companies and then taken as many as 8 companies. The analysis technique used is the classic assumption test, panel data regression analysis with a 5\% confidence level, hypothesis testing is performed using the $t$ test and $F$ test. The results of this study indicate that liquidity (Current Ratio) has no significant effect on stock prices, with a probability value of 0.980 is greater than $\alpha 0.05$. leverage (Debt to Equity) has no significant effect on stock prices, with a probability value of 0.386 , greater than $\alpha 0.05$. and profitability (Return on Equity) have no significant effect on stock prices with a probability value of 0.343 greater than $\alpha 0.05$. While simultaneous variable liquidity (Current Ratio), leverage (Debt to Equity Ratio), and profitability (Return on Equity) have no significant effect on stock prices with a prob value (F-statistic) of 0.662 greater than $\alpha 0.05$. The coefficient of determination of 0.050 or $5 \%$ means the stock price is influenced by liquidity (Current Ratio), leverage (Debt to Equity Ratio), and profitability (Return on Equity) by 5\% while the remaining 0.950 or $95 \%$ is influenced by other variables outside the research variable.
\end{abstract}

Keywords: Stock Price; Current Ratio; Debt to Equity Ratio; Return on Equity.

\section{PENDAHULUAN}

Berkembang pesatnya dunia saat ini, dengan peluang bisnis dimanamana, membuat para investor semakin banyak berinvestasi menanamkan sahamnya di pasar modal.

Pasar modal di Indonesia telah menjadi suatu lembaga investasi yang berperan penting dalam meningkatkan pertumbuhan ekonomi. Pasar modal memiliki fungsi menyediakan fasilitas untuk memindahkan dana dari pihak yang memiliki kelebihan dana (investor) kepada pihak yang membutuhkan dana (perusahaan). Pasar modal menjadi wadah alternatif bagi perusahaan untuk mendapatkan dana guna menjalankan dan mengembangkan usaha selain melalui lembaga keuangan lainnya seperti bank, koperasi dan pegadaian. Pasar modal merupakan tempat pertemuan antar perusahaan dengan individu atau 
masyarakat atau sebaliknya dan juga antar perusahaan (Erari, 2014).

Investasi merupakan penempatan sejumlah dana pada saat ini dengan harapan memperoleh keuntungan di masa mendatang (Amanda dan Pratomo, 2013).

Simamora (2010) dikutip dalam

Fitriana, Andini dan Oemar (2016) bagi perusahaan publik nilai perusahaan yang biasanya dicerminkan oleh harga pasar (market price) saham perusahaan tersebut. Para investor membeli saham biasa karena mereka mengharapkan suatu imbalan (return) atas investasi mereka. Imbalan ini dapat berupa apresiasi harga saham dan deviden kepada para pemegang saham.

Salah satu informasi yang dibutuhkan investor adalah informasi laporan keuangan atau laporan keuangan tahunan. Paling sedikit satu kali dalam setahun perusahaan publik berkewajiban menerbitkan laporan keuangan tahunan kepada investor yang ada di Bursa. publikasi laporan keuangan perusahaan (emiten) merupakan saat-saat yang ditunggu oleh para investor di pasar modal karena dari publikasi laporan keuangan itu para investor dapat mengetahui perkembangan emiten, yang digunakan sebagai salah satu pertimbangan untuk membeli atau menjual saham-saham yang dimiliki (Wingsih, 2013).

Informasi fundamental adalah informasi yang berhubungan dengan kondisi perusahaan yang umumnya ditunjukkan dalam laporan keuangan yang merupakan salah satu ukuran kinerja perusahaan. Informasi fundamental sering digunakan untuk memprediksi harga saham. Dari laporan keuangan dapat diketahui beberapa informasi fundamental antara lain: Rasio-rasio keuangan, arus kas, serta ukuran-ukuran kinerja lainnya yang dihubungkan dengan return saham (Faried, 2008).

Widoatmodjo (2000) dikutip dalam Wingsih (2013) faktor fundamental memberikan gambaran yang jelas dan bersifat analisis terhadap prestasi manajemen perusahaan dalam mengelola perusahaan yang menjadi tanggung jawabnya. Harga saham yang meningkat menggambarkan bahwa nilai perusahaan meningkat atau prestasi manajemen dalam rangka mengelola usahanya sangatlah baik. Peningkatan prestasi manajemen dapat di capai bila penggunaan modal yang dimiliki secara efektif dan efisien, hasil yang optimal dengan menggunakan keseluruhan modal perusahaan yang diinvestasikan dalam aktiva untuk menghasilkan laba atau keuntungan.

Faktor fundamental juga dapat dilihat dari beberapa rasio diantaranya Current Ratio (CR), Debt to Equity Ratio (DER), Return On Assets (ROA), Net Profit Margin (NPM). Rasio keuangan dapat menggambarkan kinerja keuangan dan dapat menjelaskan beberapa kekuatan dan kelemahan keuangan perusahaan. Rasio keuangan meliputi rasio profitabilitas yaitu Return on Assets (ROA) dan NetProfit Margin, rasio solvabilitas yaitu Debt to Equity Ratio (DER) dan rasio pasar yaitu Price to Book Value (PBV) (Faried, 2008).

$$
\text { Menurut Pasaribu }
$$
mengemukakan bahwa Faktor fundamental yang sering digunakan untuk memprediksi harga saham atau tingkat pengembalian saham adalah rasio keuangan dan rasio pasar. Rasio keuangan yang berfungsi untuk memprediksi harga saham antara lain: Return On Assets (ROA), Debt to Equity Ratio (DER) dan Book Value Per Share (BVS). Rasio pasar yang sering dikaitkan dengan harga atau tingkat pengembalian saham adalah Price Book Value (PBV).

Faktor teknikal diukur dengan beberapa indikator antara lain inflasi, nilai tukar mata uang, dan resiko pasar. Saham perusahaan yang go public adalah komoditi investasi yang berisiko, karena bersifat peka terhadap perubahan perubahan yang terjadi, baik perubahan di dalam negeri maupun perubahan dari luar negeri. Perubahan-perubahan ini tentunya merupakan risiko bagi investor. Dimana 
risiko ini antara lain risiko sistematis (Pasaribu, 2008).

Analisis fundamental yang berkaitan dengan penilaian kinerja perusahaan dan kondisi keuangan perusahaan mencapai sasaran yang dapat digunakan oleh investor sebagai pedoman dalam memperkiran harga saham yang akan datang dan keputusan investasi dalam bidang usaha yang dipilih. Salah satu bidang usaha yang membutuhkan analisis fundamental yaitu perusahaan pertambangan.

Sektor pertambangan merupakan sektor yang berperan penting bagi perekonomian nasional karena pertambangan menjadi sektor primer bagi banyak sektor, karena tidak sedikit hasil yang diproduksi oleh sektor pertambangan juga diperlukan oleh sektor lain dikutip dalam Ratih, Apriatni dan Saryadi (2013).

Perusahaan yang menjadi obyek dalam penelitian ini adalah perusahaan sub sektor batu bara pertambangan yang terdaftar di Bursa Efek Indonesia.

\section{Rumusan Masalah}

1. Apakah likuiditas (Current Ratio) berpengaruh terhadap harga saham pada perusahaan batu bara pertambangan yang terdaftar di Bursa Efek Indonesia periode 20132016 ?

2. Apakah leverage (Debt to Equity Ratio) berpengaruh terhadap harga saham pada perusahaan batu bara pertambangan yang terdaftar di Bursa Efek Indonesia periode 2013-2016?

3. Apakah profitabilitas (Return On Equity) berpengaruh terhadap harga saham pada perusahaan batu bara pertambangan yang terdaftar di Bursa Efek Indonesia periode 2013-2016?

4. Apakah likuiditas (Current Ratio), leverage (Debt to Equity Ratio) dan profitabilitas (Return On Equity) secara simultan berpengaruh terhadap harga saham pada perusahaan batu bara pertambangan yang terdaftar di
Bursa Efek Indonesia periode 20132016 ?

\section{REVIEW LITERATUR DAN HIPOTESIS}

\section{Landasan Teori \\ Harga Saham}

Harga Saham menurut Husnan dan Pudjiastuti (2004) merupakan nilai sekarang (Present Value) dari penghasilan yang akan diterima oleh pemodal dimasa yang akan datang. Sedangkan menurut Jogiyanto (2008) harga saham merupakan harga yang terjadi di pasar bursa pada saat tertentu dan harga saham tersebut ditentukan oleh pelaku pasar. Tinggi rendahnya harga saham ini ditentukan oleh permintaan dan penawaran saham tersebut di pasar modal dikutip dalam (Priatinah dan Kusuma, 2012)

\section{Analisis Fundamental}

Suatu analisis fundamental merupakan analisis yang digunakan untuk mencoba memprediksi harga saham diwaktu yang akan datang dengan mengestimasi nilai faktor-faktor fundamental yang berpengaruh terhadap harga saham diwaktu yang akan datang dan menerapkan hubungan variabelvariabel tersebut sehingga diperoleh taksiran harga saham. Model ini dikenal sebagai share price forecasting model (Faried, 2008)

\section{Likuiditas}

Dalam penelitian ini, peneliti menggunakan current ratio (CR) untuk mengukur rasio likuiditas. Rasio likuiditas digunakan untuk mengukur kemampuan perusahaan untuk memenuhi kewajiban jangka pendeknya. Current ratio digunakan untuk mencari nilai likuiditas tersebut. Current ratio (CR) didapatkan dengan membandingkan nilai aktiva lancar dengan kewajiban lancar perusahaan. Semakin tinggi nilai CR berarti semakin baik kemampuan perusahaan untuk melunasi kewajiban jangka pendeknya. 
Semakin baik kemampuan perusahaan untuk melunasi kewajibannya berarti semakin kecil resiko likuidasi yang dialami perusahaan dengan kata lain semakin kecil resiko yang harus ditanggung oleh pemegang saham perushaan (Kusumo, 2011).

$$
\text { Current Ratio }=\frac{\text { Aktiva Lancar }}{\text { Hutang Lancar }} \times 100 \%
$$

\section{Leverage}

Leverage dapat didefenisikan sebagai penggunaan aktiva atau dana dimana untuk penggunaan tersebut perusahaan harus menutup biaya tetap atau membayar beban tetap (Riyanto, 1996) dikutip dalam Asakdiyah (2015). Dalam penelitian ini, peneliti menggunakan rasio utang jangka panjang dengan ekuitas (Debt to Equity Ratio) untuk mengukur leverage.

Debt to Equity Ratio (DER) merupakan salah satu ratio leverage (solvabilitas) yang mengukur kontribusi modal sendiri dan investasi jangka panjang dalam struktur permodalan perusahaan. Debt to Equity Ratio (DER) adalah perbandingan antara hutang dan ekuitas dikutip dalam Ratih, Apriatni dan Saryadi (2013).

Rasio DER diperoleh dari perbandingan antara total hutang dengan total modal sendiri.

Debt to Equity Ratio $=\frac{\text { Total Hutang }}{\text { Total Equity }} \times 100 \%$

\section{Profitabilitas}

Dalam penelitian ini rasio profitabilitas diukur dengan Return On Equity (ROE) ROE atau imbal hasil atas ekuitas merupakan pendapatan bersih dibagi ekuitas pemegang saham (Fahmi dan Hadi 2011) dikutip dalam Wadiran (2013). ROE menerangkan laba bersih yang dihasilkan untuk setiap ekuitas. Semakin besar ROE menandakan bahwa perusahaan semakin baik dalam mensejahterakan para pemegang saham prioritas yang bisa dihasilkan dari setiap lembar saham (Wadiran,).

ROE yaitu pengukuran besarnya pengembalian terhadap investasi para pemegang saham (Putri, 2011) dikutip dalam (Wadiran, 2013). Rasio ROE bisa dihitung dengan membagi laba bersih dengan jumlah ekuitas perusahaan. Sehingga diperoleh dengan rumus sebagai berikut:

Return On Equity $=\frac{\text { Laba Bersih Setelah Bunga dan Pajak }}{\text { Total Equity }} \times 100 \%$

\section{Penelitian Terdahulu}

Beberapa penelitian tentang harga saham sudah banyak dilakukan oleh para peneliti. Diantaranya penelitian yang dilakukan oleh Ratih, Apriatni dan Saryadi (2013) yang meneliti "Pengaruh EPS, PER, DER, ROE Terhadap Harga Saham pada Perusahaan Sektor Pertambangan yang Terdaftar di Bursa Efek Indonesia (BEI) Tahun 2010-2012” yang menunjukan hasilnya bahwa Earning Per Share (EPS), Price Earning Ratio (PER), dan Return On Equity (ROE) berpengaruh positif dan signifikan terhadap harga saham. Sementara itu, Debt To Equity Ratio (DER) berpengaruh negatif terhadap harga saham. Secara simultan terdapat pengaruh yang signifikan antara Earning Per Share, Price Earning Ratio, Debt To Equity Ratio, dan Return On Equity terhadap harga saham.

Trisnawati (2015) yang meneliti "Analisis Pengaruh Current Ratio (CR), Debt to Equity Ratio (DER), Return on Equity (ROE), Net Profit Margin (NPM) dan Earning Per Share (EPS) Terhadap Harga Saham" yang menunjukan hasilnya bahwa kinerja perusahaan yang diukur dengan CR, DER, ROE, NPM dan EPS mempunyai pengaruh signifikan terhadap harga saham. Secara parsial dengan uji $\mathrm{t}$ disimpulkan bahwa secara parsial variabel CR, DER, ROE dan NPM tidak berpengaruh secara signifikan terhadap harga saham, sedangkan variabel EPS berpengaruh signifikan terhadap harga saham.

Pratama dan Erawati (2014) yang meneliti " Pengaruh Current Ratio, Debt to Equity Ratio, Return On Equity, Net Profit Margin dan Earning Per Share Terhadap Harga Saham (Study 
Kasus pada Perusahaan Manufaktur yang Terdaftar di Bursa Efek Indonesia Periode 2008-2011) yang menunjukkan hasilnya secara parsial dari kelima variabel indenpenden yang memiliki pengaruh positif dan signifikan hanya tiga variabel yaitu current ratio, debt to equity rati dan earning per share, sedangkan secara simultan dari kelima variabel independen memiliki pengaruh signifikan

\section{Hipotesis}

H1: Likuiditas (Current Ratio) berpengaruh terhadap harga saham.

$\mathrm{H} 2$ : Leverage (Debt to Equity Ratio) berpengaruh terhadap harga saham

H3: Profitabilitas (Return On Equity) berpengaruh terhadap harga saham

H4: Likuiditas (Current Ratio), leverage (Debt to Equity Ratio) dan profitabilitas (Return On Equity) berpengaruh terhadap harga saham.

\section{METODE PENELITIAN}

\section{Populasi dan Sampel}

Populasi merupakan subyek penelitian. Menurut Sugiyono (2010) populasi merupakan wilayah generalisasi yang terdiri atas obyek/subyek yang mempunyai kualitas dan karakteristik tertentu yang ditetapkan oleh peneliti untuk dipelajari dan kemudian ditarik kesimpulannya. Populasi yang digunakan dalam penelitian ini adalah saham perusahaan sub sektor batu bara pertambangan yaitu 22 perusahaan yang terdaftar di Bursa Efek Indonesia (BEI) periode 2013-2016

Sampel merupakan bagian dari populasi yang dapat mewakili karakteristik populasi tersebut. Menurut Sugiyono (2010) sampel adalah bagian dari jumlah dan karakter yang dimiliki populasi. Sampel digunakan jika populasi terlalu besar dan peneliti tidak mungkin mempelajari semua yang ada pada populasi. Sampel dalam penelitian ini yaitu perusahaan batu bara pertambangan yang terdaftar di Bursa Efek Indonesia periode 2013-2016 yang memenuhi kriteria atau pertimbangan peneliti.

\section{Definisi Operasional}

Operasional variabel adalah penentuan construct sehingga menjadi variabel yang dapat diukur. Variabel itu sendiri menurut Sugiyono (2008) adalah suatu atribut, sifat atau nilai dari orang, obyek atau kegiatan yang mempunyai variasi tertentu yang ditetapkan oleh peneliti untuk dipelajari dan diambil suatu kesimpulan.

Dalam penelitian terdapat dua variabel yaitu variabel independen dan variabel dependen. Variabel independen adalah variabel yang tidak terikat oleh factor-faktor lain, tetapi mempunyai pengaruh terhadap variabel lain. Seperti yang dikemukakan oleh Sugiyono (2008), variabel dependen adalah variabel yang dipengaruhi atau yang menjadi akibat, karena adanya variabel bebas, sedangkan variabel independen adalah variabel yang memengaruhi atau yang menjadi sebab perubahannya atau timbulnya variabel dependen. Variabel dependen dalam penelitian ini adalah Harga Saham, Sedangkan variabel independen dalam penelitian ini yaitu Current Ratio, Debt to Equity Ratio dan Return On Equity.

\section{Teknik Analisis Data}

Analisis data mempunyai tujuan untuk menyampaikan dan membatasi penemuan hingga menjadi data yang teratur dan lebih berarti. Analisis data yang digunakan pada penelitian ini adalah analisis kuantitatif yang dinyatakan dengan angka-angka yang diolah menggunakan program Eviews.

\section{Statistik Deskriptif}

Menurut Sugiyono (2012) statistik deskriptif adalah statistik yang digunakan untuk menganalisa data dengan cara mendeskripsikan atau menggambarkan data yang telah terkumpul sebagaimana 
adanya tanpa bermaksud membuat kesimpulan yang berlaku untuk umum.

\section{Uji Asumsi Klasik}

Pengujian regresi linier dapat dilakukan setelah model dari penelitian ini memenuhi syarat-syarat yaitu lolos dari asumsi klasik. Syarat-syarat yang harus dipenuhi adalah data tersebut harus terdistribusikan secara normal, tidak mengandung heteroskedastisitas, autokorelasi dan multikolinieritas. Untuk itu sebelum melakukan pengujian regresi linier berganda perlu dilakukan lebih dahulu pengujian asumsi klasik, yang terdiri dari:

\section{Uji Normalitas}

Pengujian normalitas memiliki tujuan untuk menguji apakah dalam model regresi, variabel pengganggu atau residual memiliki distribusi normal. Seperti diketahui bahwa uji $\mathrm{T}$ dan uji $\mathrm{F}$ mengasumsikan bahwa nilai residual mengikuti distribusi normal. Kalau asumsi ini dilanggar maka uji statistik menjadi tidak valid untuk jumlah sampel kecil. Untuk menguji normalitas data, penelitian ini menggunakan analisis grafik. Pengujian normalitas melalui analisis grafik adalah dengan cara menganalisis grafik normal probability plot yang membandingkan distribusi kumulatif dari distribusi normal. Uji statistik lain yang dapat digunakan untuk menguji normalitas residual adalah uji Jarque-Berra Jika hasil dari uji J-B menunjukkan nilai prob. J-B di atas 0,05 maka data residual terdistribusi dengan normal.

\section{Uji Multikolinearitas}

Multikolinieritas adalah adanya suatu hubungan linier yang sempurna antara beberapa atau semua variabel independen. Uji multikolinieritas bertujuan untuk menguji apakah model regresi ditemukan adanya korelasi antar variabel bebas (independen). Model regresi yang baik seharusnya tidak terjadi korelasi diantara variabel bebas (Ghozali,
2006). Cara pengujian multikolinieritas pada penelitian adalah dengan nilai korelasi antar variabel independen dengan pengambilan keputusannya adalah bila nilai korelasi antar variabel independen > 0.85 maka terdapat multikolinieritas (Widarjono, 2013) Bila ada variabel independen yang terkena multikolinieritas, maka salah satu cara penanggulangannya adalah salah satu dari variabel yang terkena multikolinieritas tersebut dikeluarkan (Ghozali, 2006).

\section{Uji Heteroskedastisitas}

Uji heteroskedastisitas ini bertujuan untuk menguji apakah dalam model regresi terjadi ketidaksamaan varians dari residual satu pengamatan ke pengamatan lain. Jika varians dari satu pengamatan ke pengamatan yang lain tetap, maka disebut homoskedositas atau tidak terjadi heteroskedastisitas. Dan jika varians berbeda maka disebut heteroskedastisitas. Model regresi yang baik adalah yang homoskedastisitas atau tidak terjadi heteroskedasitas (Ghozali, 2006).

\section{Uji Autokorelasi}

Uji autokorelasi bertujuan untuk mengetahui apakah dalam suatu model regresi linier terdapat korelasi antara pengganggu pada periode $\mathrm{t}$ dengan kesalahan pada periode t-1 (sebelumnya). Model regresi yang baik adalah regresi yang bebas dari autokeralsi (Ghozali, 2006). Alat analisis yang digunakan adalah uji DurbinWatson. Untuk mengetahui terjadi atau tidak autokorelasi dilakukan dengan membandingkan nilai statistik hitung Durbin Watson pada perhitungan regresi dengan statistik tabel Durbin Watson pada tabel.

\section{Regresi Data Panel}

Dalam pengujian analisis regresi terdapat tiga model yang bisa digunakan yaitu: ordinary least square atau common effect, fixed effect, dan random effect. Pada penentuan model akan digunakan uji Chow 
(redundant fixed effect test) dan uji Hausman (correlated random effect test) yang dibantu dengan menggunakan software statistic Eviews.

Variabel independen yang digunakan terdiri dari likuiditas (CR), leverage (DER) dan profitabilitas (ROE). Variabel dependen dalam penelitian ini adalah harga saham perusahaan sub sektor batu bara pertambangan go public yang terdaftar di BEI periode 2013-2016.

Model regresi data panel dapat dirumuskan sebagai berikut:

$$
\begin{array}{ll}
\mathrm{Y}=\alpha+ & \beta_{1} \mathrm{X} 1+\beta_{2} \mathrm{X} 2+\beta_{3} \mathrm{X} 3+\mathrm{e} \\
\mathrm{Y} & =\text { Harga saham } \\
\alpha & =\text { Konstanta } \\
\beta_{1}-\beta_{5} & =\text { Koefisien regresi } \\
\mathrm{X} 1 & =\text { Likuiditas (Current Ratio) } \\
\mathrm{X} 2 & =\text { Leverage (Debt to Equity Ratio) } \\
\mathrm{X} 3 & =\text { Profitabilitas (Return On Equity) } \\
\mathrm{e} & =\text { eror }
\end{array}
$$

\section{Uji Hipotesis}

\section{Uji Parsial (Uji T)}

Uji t pada dasarnya menunjukkan seberapa jauh pengaruh satu variabel penjelas/independen secara individual dalam menerangkan variasi variabel dependen. Pengambilan keputusan penelitian ini diperoleh dengan cara membandingkan t-statistik masing masing variabel independen dengan $\mathrm{t}$ tabel (one-tail) pada tingkat alpha yang ditentukan. Apabila t-statistik lebih besar dari t-tabel (one tail) dengan arah yang sesuai maka hipotesis alternatif diterima yang artinya variabel independen tersebut berpengaruh secar signifikan terhadap variabel dependennya, dan begitu pula sebaliknya.

2. Uji F (Simultan)

Uji Secara Simultan (uji F) Uji ini dilakukan untuk mengetahui pengaruh variabel independen terhadap variabel $\begin{array}{lll}\begin{array}{l}\text { dependen } \\ \text { (bersamasama) }\end{array} & \text { secara simultan }\end{array}$

3. Uji Koefisien Determinasi

Uji $\mathrm{R}_{2}$ digunakan untuk menguji seberapa besar kemampuan model dalam menerangkan variasi variabel dependen. Nilai koefisien determinasi adalah antar nol sampai satu $\left(0<\mathrm{R}^{2}<1\right)$. Nilai $\mathrm{R}^{2}$ yang kecil berarti kemampuan variabel - variabel independen dalam menjelaskan variasi variabel dependen amat terbatas. Nilai yang mendekati satu berarti variabel-variabel independen memberikan hampir semua informasi yang dibutuhkan untuk memprediksi variasi variabel dependen (Ghozali, 2006).

\section{HASIL PENELITIAN DAN PEMBAHASAN}

\section{Statistik Deskriptif}

\begin{tabular}{|l|c|c|c|c|}
\hline \multirow{2}{*}{} & LNHARGASAHAM & LNCR & LNDER & LNROE \\
\hline Mean & & & & \\
& 7.564 & 5.162 & 4.075 & 2.493 \\
\hline Median & 7.282 & 5.185 & 4.226 & 2.737 \\
\hline Maximum & 10.257 & 6.063 & 4.934 & 3.438 \\
\hline Minimum & & & & \\
& 6.040 & 3.899 & 2.772 & -0.174 \\
\hline Std. Dev. & 1.185 & 0.487 & 0.509 & 0.822 \\
\hline \multicolumn{4}{|c|}{ Sumber: Hasil olah data eviews 9,2017 } \\
\hline
\end{tabular}

Berdasarkan tabel 4.1 dapat dilihat nilai statistik variabel harga saham memiliki rata-rata sebesar 7.564 , nilai tengah atau median sebesar 7.282 dengan nilai maksimum 10.257 dan nilai minimum sebesar 6.040 serta nilai standar deviasi 1.185. Nilai statistik variabel $\mathrm{CR}$ memiliki rata-rata sebesar 5.162 , nilai tengah atau median sebesar 5.185 dengan nilai maksimum 6.063 dan nilai minimum sebesar 3.899 serta nilai standar deviasi 0.487. Nilai statistik variabel DER memiliki rata-rata sebesar 4.075 nilai tengah atau median sebesar 4.226 dengan nilai maksimum 4.934 dan nilai minimum sebesar 2.772 serta nilai standar deviasi 
0.509. Nilai statistik variabel ROE memiliki rata-rata sebesar 2.493 , nilai tengah atau median sebesar 2.737 dengan nilai maksimum 3.438 dan nilai minimum sebesar -0.174 serta nilai standar deviasi 0.822 .

\section{Uji Normalitas}

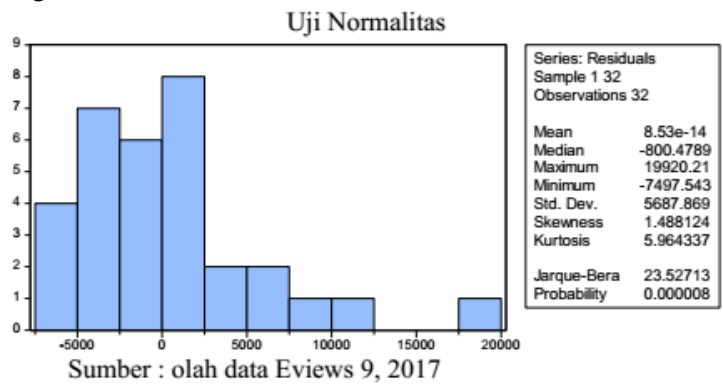

Pada tabel di atas menunjukkan bahwa residual persamaan regresi pada uji normalitas tersebut berdistribusi tidak normal. Hal ini ditunjukkan pada nilai prob. J-B sebesar 0,0000008 , yang mana lebih besar dari $5 \%(0,0000008<0,05)$.

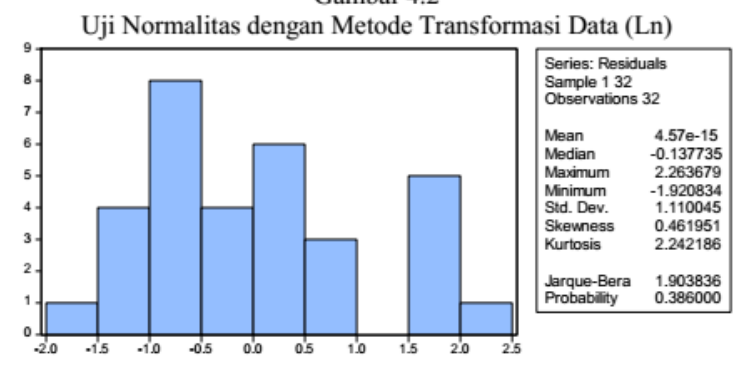

Pada tabel di atas menunjukkan bahwa residual persamaan regresi pada uji normalitas tersebut berdistribusi normal. Hal ini ditunjukkan pada nilai prob. J-B sebesar 0,0000008, yang mana lebih besar dari $5 \% 0.386000>0,05)$.

\section{Uji Autokorelasi}

\begin{tabular}{|c|c|}
\hline \multicolumn{2}{|c|}{ Uji Autokolerasi } \\
\hline Jenis pengujian & Prob. Chi square \\
\hline Breusch-Godfrey & 0.0049 \\
\hline \multicolumn{2}{|c|}{ Sumber : olah data Eviews 9,2017} \\
\hline \multicolumn{2}{|c|}{ Uji Autokolerasi dengan Invers } \\
\hline Jenis pengujian & Prob. Chi square \\
\hline Breusch-Godfrey & 0.8439 \\
\hline
\end{tabular}
menunjukan bahwa nilai prob. ChiSquare 0.8439 lebih besar dari $\alpha 0.05$ (0.8439 > 0.05), dapat disimpulkan bahwa bebas dari masalah autokorelasi.
Uji Heteroskedastisitas

\begin{tabular}{|l|c|}
\hline Jenis pengujian & Prob. Chi square \\
\hline Uji White & 0.1320 \\
\hline Sumber : olah data Eviews 9, 2017 &
\end{tabular}

Hal ini di tunjukkan pada nilai prob chi square berdasarkan uji White sebesar 0.1320 yang lebih besar dari $\alpha$ 5\% (0.1320 $>0.05)$ dan disimpulkan bahwa tidak ada masalah heteroskedastisitas.

\section{Uji Multikolinearitas}

\begin{tabular}{|c|c|c|c|}
\hline & Uji Multikolonieritas \\
\hline LNCR & LNCR & LNDER & LNROE \\
\hline LNDER & 1.000 & -0.518 & -0.009 \\
\hline LNROE & -0.518 & 1.000 & 0.176 \\
\hline
\end{tabular}

Berdasarkan hasil output diatas terlihat bahwa hubungan antara variabel Current Ratio dengan Debt to Equity Ratio sebesar -0.518 yang lebih kecil dari 0.90, hubungan Current Ratio dengan Return on Equity sebesar -0.009 yang lebih kecil dari 0.90, hubungan variabel Debt to Equity Ratio dengan Return On Equity sebesar 0.176 yang lebih kecil dari 0.90, dari penjelasan tersebut model regresi terbebas dari masalah multikolinieritas karena nilai korelasi (CR, DER dan ROE) lebih kecil dari $90 \%$ atau 0.90

\section{Regresi Data Panel}

\begin{tabular}{|c|c|c|}
\multicolumn{3}{c}{ Uji Chow } \\
\hline $\begin{array}{c}\text { Effect Test } \\
\text { Cros-section Chi- } \\
\text { square }\end{array}$ & Prob & Kesimpulan \\
\hline
\end{tabular}

Sumber : olah data Eviews 9. 2017

Berdasarkan tabel diatas uji chow

lebih besar dari a 5\% (0.1949> 0.05) hasil ini menyimpulkan bahwa model Common Effect.

\section{Uji Hipotesis}

\begin{tabular}{|c|c|c|c|c|}
\multicolumn{7}{c}{ Hasil Uji Analisis Regresi Data Panel } \\
\hline Variabel & Coefficient & Std. Error & t- statistik & Prob \\
\hline C & 7.333 & 3.555 & 2.066 & 0.048 \\
\hline LNCR & -0.009 & 0.385 & -0.024 & 0.980 \\
\hline LNDER & -0.588 & 0.668 & -0.879 & 0.386 \\
\hline LNROE & 0.475 & 0.493 & 0.963 & 0.3433 \\
\hline
\end{tabular}
Sumber : olah data Eviews 9, 2017
Dari analisis regresi

berganda pada tabel maka persamaan analisis regresi sebagai berikut : 
$\mathrm{LNY}=7.333-0.009$ LNCR -0.588

LNDER + 0.475 LNROE + e

Hası Uj1 Parsial (Uj1 t)
\begin{tabular}{|c|c|c|c|}
\hline Variabel & Cofficient & Prob & Keterangan \\
\hline C & 7.333 & 0.048 & \\
\hline LNCR & -0.009 & 0.980 & Tidak Signifikan \\
\hline LNDER & -0.588 & 0.386 & Tidak Signifikan \\
\hline LNROE & 0.475 & 0.343 & Tidak signifikan \\
\hline
\end{tabular}
Sumber : Olah data eviews 9, 2017

Uji hipotesis pertama dilakukan untuk mengetahui ada tidaknya pengaruh antara Current Ratio (CR) tehadap harga saham. Untuk menjawab hipotesis pertama dalam penelitian ini peneliti membandingkan nilai signifikan dengan $\alpha 5 \%$. Nilai koefisien regresi sebesar -0.009 dan nilai signifikan CR sebesar 0.980>0.05 maka hipotesis pertama $\left(\mathrm{H}_{1}\right)$ ditolak, $\left(\mathrm{H}_{0}\right)$ diterima. Hasil penelitian ini menunjukan Current Ratio secara parsial tidak signifikan terhadap harga saham

Uji hipotesis kedua dilakukan untuk mengetahui ada tidaknya pengaruh antara Debt to Equity Ratio (DER) tehadap harga saham. Untuk menjawab hipotesis kedua dalam penelitian ini peneliti membandingkan nilai signifikan dengan $\alpha$ $5 \%$. Nilai koefisien regresi sebesar -0.588 dan nilai signifikan DER sebesar 0.386>0.05 maka hipotesis kedua $\left(\mathrm{H}_{2}\right)$ ditolak, $\left(\mathrm{H}_{0}\right)$ diterima. Hasil penelitian ini menunjukan bahwa Debt to Equity Ratio tidak signifikan terhadap harga saham.

Uji hipotesis ketiga dilakukan untuk mengetahui ada tidaknya pengaruh antara Return on Equity (ROE), tehadap harga saham Untuk menjawab hipotesis ketiga dalam penelitian ini peneliti membandingkan nilai signifikan dengan $\alpha$ 5\%. Nilai koefisien regresi sebesar 0.475 dan nilai signifikan ROE sebesar 0.343>0.05 maka hipotesis ketiga $\left(\mathrm{H}_{3}\right)$ ditolak, $\left(\mathrm{H}_{0}\right)$ diterima. Hasil penelitian ini menunjukan bahwa variabel Return on Equity tidak signifikan terhadap harga saham.

\section{Uji F (Simultan)}

Hasil Uji Pengaruh Simultan

\begin{tabular}{|c|c|}
\hline Prob ( F-statistic) & 0.662 \\
\hline Sumber : Olah data eviews 9, 2017
\end{tabular}

Berdasarkan tabel 4.9 menunjukan bahwa hasil pernelitian diperoleh nilai signifikan sebesar 0.662 yang dimana lebih besar dari $\alpha \quad 0.05 \quad(0.662>0.05)$ artinya (H0) diterima. Hasil penelitian ini menunjukan bahwa Current Ratio (CR), Debt to Equity Ratio (DER) dan Return on Equity (ROE) secara simultan tidak signifikan terhadap harga saham.

\section{Uji Koefisien Determinasi $\left(\mathrm{R}^{2}\right)$}

1 aber 4.10

Hasil Uji Koefisien Determinasi

\begin{tabular}{|c|c|}
\hline R-squared & 0.050 \\
\hline \multicolumn{2}{|c|}{ Sumber :Olah data eviews 9, 2017} \\
\hline
\end{tabular}

Berdasarkan tabel 4.10 hasil penelitian diperoleh nilai Rsquare sebesar 0.050. Hasil ini menunjukan bahwa variabel harga saham dijelaskan oleh Current Ratio (CR), Debt to Equity Ratio (DER) dan Return on Equity (ROE), sebesar 0.050 atau $5 \%$ sedangkan sisanya 0.950 atau $95 \%$ harga saham dipengaruhi oleh variabel lain diluar variabel penelitia

\section{Pembahasan \\ Pengaruh likuiditas (Current Ratio) terhadap harga saham}

Berdasarkan hasil pengolahaan data yang ditunjukkan tabel 4.8 menunjukkan bahwa variabel current ratio (CR) tidak signifikan terhadap harga saham atau karena t.sig (0.980) lebih besar dari $\alpha 0.05(0.980>0.05)$.

CR merupakan rasio likuiditas yang digunakan untuk mengukur kemampuan perusahaan dalam melunasi hutang jangka pendek. Semakin besar CR maka semakin tinggi kemampuan perusahaan membayar hutang jangka pendeknya. Dalam penelitian ini teori CR tidak dapat digunakan karena tinggi rendahnya $\mathrm{CR}$ tidak berpengaruh minat investor menanamkan modalnya. Besar kecilnya $\mathrm{CR}$ perusahaan 
tersebut belum dapat mempengaruhi harga saham.

Salah satu faktor antara CR dan harga saham tidak signifikan yaitu nilai $\mathrm{CR}$ tidak konsisten atau bervariatif dan tidak sesuai dengan harga saham, maksudnya ketika CR naik tetapi harga saham turun dan sebaliknya ketika CR turun harga saham naik. Misalnya perusahaan BSSR tahun 2013 harga sahamnya lebih tinggi dibanding harga saham tahun 2014, pada tahun 2013 nilai CR sebesar 49,39 dengan harga saham 1950 sedangakan pada tahun 2014 nilai CR sebesar 67,04 dengan harga saham 1590. Hal yang sama dialami juga perusahaan lain yaitu ADRO 2015, BSSR 2015, GEMS 2014, GEMS 2015, ITMG 2015, KKGI 2015, MYOH 2014, PTBA 2014, TOBA 2015 dan TOBA 2016. Selain itu yang menyebabkan $\mathrm{CR}$ bepengaruh tidak signifikan terhadap harga saham yaitu dalam uji asumsi klasik terjadi autokolerasi dan datanya tidak berdistribusi normal.

Sehingga dari penelitian ini menunjukan bahwa variabel $\mathrm{CR}$ tidak digunakan oleh para investor sebagai pertimbangan dalam berinvestasi pada suatu perusahaan. $\mathrm{CR}$ tidak signifikan terhadap harga saham penelitian ini didukung oleh Trisnawati (2015) dimana penelitiannya menunjukan bahwa Current Ratio menunjukan tidak signifikan terhadap harga saham.

\section{Pengaruh leverage (Debt to Equity Ratio) terhadap harga saham}

Data yang ditunjukkan tabel 4.8 menunjukkan bahwa variabel Debt to Equity Ratio mempunyai pengaruh yang signifikan terhadap harga saham karena t.sig 0.386 lebih besar dari $\alpha$ 0.05 (0.386>0.05). Debt to Equity Ratio (DER) merupakan salah satu ratio leverage (solvabilitas) yang mengukur kontribusi modal sendiri dan investasi jangka panjang dalam struktur permodalan perusahaan. Debt to Equity Ratio adalah rasio yang digunakan untuk mengukur tingkat penggunaan utang terhadap ekuitas yang dimiliki perusahaan. Semakin rendah DER menandakan modal yang digunakan dalam operasional perusahaan semakin kecil, sehingga risiko yang ditanggung investor juga akan semakin kecil dan akan mampu meningkatkan harga saham. Semakin besar DER menunjukkan bahwa struktur modal lebih memanfaatkan hutang dibandingkan dengan modal sendiri. Dalam penelitian ini teori DER tidak dapat digunakan karena tinggi rendahnya DER perusahaan belum dapat mempengaruhi naik turunnya harga saham. Salah satu faktor antara DER tidak signifikan terhadap harga saham dikarenakan ketika DER naik atau hutang perusahaan tinggi tetapi harga saham naik juga bukan turun dan sebaliknya ketika DER turun atau hutang perusahaan kecil tetapi harga saham turun juga bukan naik. Penelitian ini menunjukan besar kecilnya DER tidak mempengaruhi investor menanamkan modalnya. Misalnya pada perusahaan ADRO tahun 2014 nilai DER turun dari tahun sebelumnya atau tahun 2013, pada tahun 2013 DER sebesar 111 dengan harga saham 1090 dan pada tahun 2014 nilai DER turun menjadi 97 dengan harga saham 1040. Hal yang sama dialami juga perusahaan lain yaitu ADRO 2015, BSSR 2015, GEMS 2014, ITMG 2015, KKGI 2014, KKGI 2015, MYOH 2014 dan TOBA 2015. Selain itu yang menyebabkan DER berpengaruh tidak signifikan terhadap harga saham yaitu dalam uji asumsi klasik terjadi autokolerasi dan datanya tidak berdistribusi normal. Sehingga dari penelitian ini menunjukan bahwa variabel DER tidak digunakan oleh para investor sebagai pertimbangan dalam berinvestasi pada suatu perusahaan. DER tidak signifikan terhadap harga saham penelitian ini didukung oleh Trisnawati (2015) dimana penelitiannya menunjukan bahwa Debt to Equity Ratio menunjukan tidak signifikan terhadap harga saham. 
Pengaruh profitabilitas (Return on Equity) terhadap harga saham

Berdasarkan hasil pengolahan data yang ditunjukkan tabel 4.8 menunjukkan bahwa variabel hasil dari Return on Equity terhadap harga saham tidak signifikan terhadap harga saham karena t.sig sebesar 0.343 lebih besar dari $\alpha 0.05(0,343>0,05)$. Return on Equity merupakan rasio yang digunakan untuk mengukur kemampuan perusahaan memperoleh laba atau keuntungan pada hasil penjualan. Semakin tinggi ROE akan menunjukan kinerja perusahaan yang baik dan harga saham perusahaan akan meningkat.

Dalam penelitian ini ROE memiliki pengaruh tidak signifikan berarti tinggi rendahnya ROE tidak akan mempengaruhi investor dalam menanamkan modalnya, hal ini disebabkan karena apabila perusahaan mampu mengelolah modalnya dengan baik maka akan menghasilkan profit, tidak semua perusahaan yang modalnya menurun akan berpengaruh terhadap harga saham perusahaan tersebut.

Dalam penelitian ini teori ROE tidak dapat digunakan karena tinggi rendahnya ROE perusahaan belum dapat mempengaruhi naik turunnya harga saham. Salah satu faktor antara ROE tidak signifikan terhadap harga saham dikarenakan ketika ROE naik atau laba perusahaan tinggi tetapi harga saham turun dan sebaliknya ketika ROE turun atau laba perusahaan kecil tetapi harga saham naik. Misalnya pada perusahaan MYOH 2016 nilai ROE turun dibanding tahun 2015 yaitu pada tahun 2016 nilai ROE sebesar 19,77 dengan harga saham 630 sedangkan tahun 2015 nilai ROE sebesar 26,5 dengan harga saham 525. Hal yang sama dialami juga perusahaan lain yaitu BSSR 2015, BSSR 2016, MYOH 2014, PTBA 2014, PTBA 2016, TOBA 2014 dan TOBA 2016. Selain itu yang menyebabkan ROE berpengaruh tidak signifikan terhadap harga saham yaitu dalam uji asumsi klasik terjadi autokolerasi dan datanya tidak berdistribusi normal.
Sehingga dari penelitian ini menunjukan bahwa variabel ROE tidak mempengaruhi harga saham. Hasil penelitian didukung penelitian yang dilakukan oleh Trisnawati (2015)

\section{Pengaruh likuiditas (Current Ratio), leverage (Debt to Equity Ratio), profitabilitas (Return on Equity) terhadap harga saham.}

Dari hasil uji F (uji simultan) variabel independent likuiditas (Current Ratio), leverage (Debt to Equity Ratio), profitabilitas (Return on Equity) tidak signifikan terhadap harga saham yaitu dengan nilai prob (Fstatistic) sebesar 0.662 lebih besar dari $\alpha 0.05(0.662>0.05)$. Hal ini menunjukan bahwa hipotesis keempat ditolak. Dengan demikian dapat disimpulkan bahwa variabel likuiditas (Current Ratio), leverage (Debt to Equity Ratio), profitabilitas (Return on Equity) berpenagruh tidak signifikan secara simultan terhadap harga saham

\section{KESIMPULAN DAN SARAN}

\section{Kesimpulan}

Penelitian ini bertujuan untuk mengetahui hasil pengaruh likuiditas (Current Ratio), leverage (Debt to Equity Ratio), profitabilitas (Return on Equity) terhadap harga saham pada perusahaan batu bara pertambangan yang tedaftar di Bursa Efek Indonesia (BEI) periode tahun 2013 - 2016.

1. Hipotesis pertama (H1) ditolak, yang menunjukan bahwa Current Ratio berpengaruh tidak signifikan terhadap harga saham.

2. Hipotesis kedua (H2) ditolak, yang menunjukan bahwa Debt to Equity Ratio berpengaruh tidak signifikan terhadap harga saham.

3. Hipotesis ketiga (H3) ditolak, yang menunjukan bahwa Return on Equity berpengaruh tidak signifikan terhadap harga saham. 
4. Hipotesis keempat (H4) menunjukan bahwa likuiditas (Current Ratio), leverage (Debt to Equity Ratio) dan profitabilitas (Return on Equity) berpengaruh tidak signifikan secara simultan terhadap harg

\section{Saran}

1. Bagi peneliti selanjutnya

a. Menambah variabel lain diluar variabel penelitian ini yang berkaitan dengan variabel fundamental untuk mengetahui lebih banyak dan jelas mengenai faktor - faktor yang mempengaruhi harga saham

b. Perlu dilakukannya penelitian kembali dengan objek penelitian selain perusahaan pertambangan. Memperpanjang periode yang diteliti, karena semakin panjang periode yang diteliti hasil yang diperoleh semakin akurat.

2. Bagi pihak perusahaan Penyediaan laporan keuangan yang lengkap dan jelas untuk mengurangi informasi asimetri dan sebagai sumber informasi mengenai kondisi keuangan perusahaan sehingga dapat menyakinkan investor untuk menanamkan sahamnya.

\section{DAFTAR PUSTAKA}

Ayuningrum, Anggrainy Putri. 2011. "Analisis Pengaruh CAR, NPL, BOPO, NIM dan LDR terhadap ROA" Skripsi Universitas Diponegoro Semarang.

Amanda, WBBA dan Wahyu Ario Pratomo. 2013. "Analisis Fundamental dan Resiko Sistematik terhadap Harga Saham Perbankan yang Terdaftar pada Indeks LQ 45" Jurnal Ekonomi dan Keuangan (Februari). Vol. 1, No. 3.
Asakdiyah, Salamatun. 2006. Manajemen Keuangan I Alat Analisis dan Aplikasi. Yogyakarta: Universitas Ahmad Dahlan

Asakdiyah, Salamatun. 2015. Manajemen keuangan II Alat Analisis dan Aplikasi. Yogyakarta: Universitas Ahmad Dahlan.

Erari, Anita. 2014. "Analisis Pengaruh Current Ratio, Debt to Equity Ratio dan Return On Asset Terhadap Return Saham pada Perusahaan Pertambangan di Bursa Efek Indonesia" Jurnal Manajemen dan Bisnis (September), Vol.5, No.2, Hal. 175-191.

Faried, Asbi Rachman. 2008. Analisis Pengaruh Faktor Fundamental dan Nilai Kapitalis Pasar Terhadap Return Saham Perusahaan Manufaktur di BEI.Tesis (tidak diterbitkan). Semarang: Universitas Diponegoro.

Fitriana, Dewi, Rita Andini dan Abrar Oemar. 2016. "Pengaruh Likuiditas, Solvabilitas, Profitabilitas, Aktivitas dan Kebijakan Dividen Terhadap Return Saham Perusahaan Pertambangan yang Terdaftar pada BEI Periode 2007-2013" Journal Of Accounting (Maret).Vol.2, No.2.

Kusuma, Desta Rizky dan Deny Ismanto. 2012. Modul Pratikum Eviews. Yogyakarta: Universitas Ahmad Dahlan

Kusumajaya, Dewa Kadek Oka. 2011. "Pengaruh Struktur Modal dan Pertumbuhan Perusahaan Terhadap Profitabilitas dan Nilai Perusahaan pada Perusahaan Manufaktur di Bursa Efek Indonesia”. Tesis (tidak diterbitkan).Denpasar:Universitas Udayana Denpasar. 
Kusumo, RM Gian Ismoyo. 2011. "Analisis Pengaruh Rasio Keuangan Terhadap Return Saham pada Perusahaan Non Bank LQ 45" Skripsi (tidak diterbitkan). Semarang:Universitas Diponegoro.

Pasaribu, Rowland Bismark Fernando. 2009. "Pengaruh Variabel Fundamental Terhadap Harga Saham Perusahaan Go Public di BEI" Jurnal Ekonomi dan Bisnis (Juli). Vol. 2, No.2, Hal.101-113.

Pratama, Aditya dan Teguh Erawati. 2014. "Pengaruh Current Ratio, Debt to Equity Ratio, Return on Equity, Net Profit Margin dan Earning Per Share terhadap Harga saham (Study Kasus pada Perusahaan Manufaktur yang Terdaftar di Bursa Efek Indonesia periode 2008-2011)" Jurnal Akuntansi (Juni). Vol. 2 No.1, Hal 1-9

Priatinah, Denies dan Prabandaru Adhe Kusuma. 2012. " Pengaruh Return OnInvestment (ROI), Earning Per Share (EPS) dan DividenPer Share (DPS) Terhadap Harga Saham Perusahaan Pertambangan yang Terdaftar di Bursa Efek Indonesia (BEI) Periode 2008-2010" Jurnal Nominal. Vol. 1, No 1, Hal 50-64.

Ratih, Dorothea , Apriatni E.P dan Saryadi. 2013. "Pengaruh EPS, PER, DER, ROE Terhadap Harga Saham pada Perusahaan Sektor Pertambangan yang Terdaftar di Bursa Efek Indonesia (BEI) Tahun 2010-2012" Journal Of Social And Politic, No 3, Vol 1 Hal. 1-12.

Sandhieko, Hendri Harryo. 2009. “ Analisis Rasio Likuiditas, Rasio Leverage, dan Rasio Profitabilitas serta Pengaruhnya Terhadap Harga Saham pada Perusahan-Perusahaan Sektor Pertambangan yang Listing di
BEI" Skripsi (tidak diterbitkan).Bandung:Universitas Widyatama.

Sugiyono. 2010. Metode Penelitian Administrasi: Pendekatan Kuantitatif,

Kualitatif dan $R \& D$. Bandung : Alfabeta

Sutriani, Anis. 2014. "Pengaruh Profitabilitas, Leverage, dan Likuiditas Terhadap Return Saham dengan Nilai Tukar sebagai Variabel Moderasi pada Return Saham LQ45" Journal of Business and Banking (May).Vol. 4, No. 1, pages $67-80$.

Trisnawati, Mamik. 2015. "Analisis Pengaruh Current Ratio (CR), Debtto Equity Ratio (DER), Return On Equity (ROE), Net Profit Margin (NPM) dan Earning Per Share (EPS) Terhadap Harga Saham" Skripsi (tidak diterbitkan). Semarang: Universitas Dian Nuswantoro.

Wadiran, Mega Monica. 2013. “FaktorFaktor yang Mempengaruhi Expected Return Saham pada Pertambangan Batu Bara yang Terdaftar di Bursa Efek Indonesia Periode 2007-2011" Jurnal Manajemen (September) Vol.1 No.3 , Hal. 1129-1139.

Wingsih, Yuliya. 2013. "Analisis Pengaruh Likuiditas, Profitabilitas dan Solvabilitas Terhadap Return Saham pada Perusahaan Pertambangan yang Terdaftar di Bursa Efek Indonesia pada Tahun 2008 Sampai 2012" Skripsi (tidak diterbitkan). Semarang: Universitas Dian Nuswantoro.

www.idx.co.id

www.sahamok.com 